\author{
A C G \\ Org. Commun. 11:4 (2018) 181-187 \\ publications
}

organic

communications

\title{
Chemoselective reduction for different steroidal $\alpha, \beta$-unsaturated ketone into diene by using Luche reagent
}

\author{
Khaled Q. Shawakfeh $\odot^{*}$, Raed Al-Zoubi $\odot$, Walid Al-Jammal $\odot$ and \\ Rasha Nusier
}

Jordan University of Science \& Technology, Department of Chemistry, Irbid, 22110, Jordan

(Received November 04, 2018; Revised December 09, 2018; Accepted December 13, 2018)

\begin{abstract}
The conjugate reduction of $\alpha, \beta$-unsaturated carbonyl compounds remains an active area of organic synthesis. Our aim is to control the reducing potential and selectivity of conjugated enone reduction. After much experimentation, the best conditions found for maximum yield with chemo and regioselectivity were to employ 1 molar equiv. of $\mathrm{NaBH}_{4}$ for each mole of substrate in methanol containing some cerium(III) chloride. Many enones were converted essentially quantitatively to the allylic alcohol at room temperature. Surprisingly, reduction of the enone system in compound $2(1.0 \mathrm{mmol})$ with $\mathrm{NaBH}_{4}(1.0 \mathrm{mmol})$ and cerium chloride $(1.0 \mathrm{mmol})$ in $\mathrm{MeOH}$ gave compound $\mathbf{3}$, in which the enone system was reduced and the allylic alcohol dehydrated producing the diene system.
\end{abstract}

Keywords: Regioslective; chemoselective; reduction; Luche reagent; diene; ketone. @2018 ACG Publications. All right reserved.

\section{Introduction}

The synthesis of natural products is a subject of considerable interest. One of the most fundamental and useful reactions in organic synthesis is the reduction. During the past decades, sodium borohydride has been known as mild and selective reducing agents. The nature of the cation associated with the tetracoordinated borohydride, as well as the choice of the solvent is important in performing selective reduction step. However, reduction of unsaturated carbonyl compounds with sodium borohydride, is highly solvent dependent and generally does not result in a significant regioselectivity. ${ }^{1,2}$ Therefore, combination of $\mathrm{NaBH}_{4}$ with Lewis acids ${ }^{3,4}$ such as Luche reduction ${ }^{5,6}$ was used to control the reducing potential and selectivity of $\mathrm{NaBH}_{4}$ in the 1,2-reduction of conjugated enone system. It is believed that the electrophilic assistance occur by either when the cation act as Lewis acid or when the reaction run in a protic solvent. ${ }^{7}$ It was reported that steroidal enone gave the corresponding equatorial allyl alcohol with a high regioselectivity under complexation control when the reaction carried out by using Luche reagent $\left(\mathrm{NaBH}_{4} / \mathrm{CeCl}_{3}\right.$ in $\left.\mathrm{MeOH}\right)$. The interpretation for this regioselectivity was proposed by considering that these reductions take place mainly under Frontier control, and that the enone LUMOcation interaction is the predominant one. The lower the LUMO level of enone, according to the strength of the interaction with the cation, the faster is the reduction. Therefore, the regioselectivity depends on the relative magnitude of the carbonyl carbon C-2 and the C-4 double bond carbon in the LUMO of the complexed enone system. ${ }^{8}$

* Corresponding author: E-Mail: shawakfa@just.edu.jo, Phone: + 96222701000; Fax: +96227095014. 
This reaction has continued to attract synthetic chemists and was reported by Zhang and coworkers that it can be utilized for deoxygenation of $\alpha, \beta$-unsaturated acylphenols to obtain 2allylphenols. ${ }^{9}$ Recently, H.B. Borate found during the course of his research involving the Luche reduction of 2-aryl-4-hydroxycyclopent-2-en-1-ones that selective deoxygenation is taking place wherein protected/unprotected hydroxyl functionality is used to afford the 2-aryl-cyclopent-2-en-1-ones in good yields. It is noteworthy that this result for deoxygenation of hydroxyl functionality under Luche reduction conditions is the first time reported in the literature. ${ }^{10}$ This inspired us to study the stereo and chemoselective reduction of our steroidal enone to diene systems using $\mathrm{NaBH}_{4} / \mathrm{CeCl}_{3}$. We believe that the enone system could be reduced and the allylic alcohol dehydrated upon presence of basic functional groups such as the polyamine side chain to produce the requested diene system.

In our research group, we synthesized several steroidal polyamine and steroidal diamine dimers that mimic the structure of Squalamine and Retrazine, which possess numerous therapeutic properties such as antiangiogenics and antimicrobial and could be safely administered to cancer patients. ${ }^{11-14}$ It is known that increasing the polar functionalities is expected to increase the biological activities of these steroidal amine compounds. Therefore, we were interested in regioselective reduction of some carbonyl functionalities into ally alcohol. This subject and our continuous efforts to explore new hydroxylated steroidal amine and dimeric steroidal amine encouraged us to investigate reduction of carbonyl functional groups by the Luche reagent. Herein, we wish to introduce an unexpected method for the reduction of a steroidal enone system into the steroidal diene system. There is no reported literature evidence for this unique reduction until this moment.

\section{Experimental}

\subsection{Chemical material and apparatus}

Melting points $(\mathrm{mp})$ were determined on an electrothermal digital melting point apparatus. Materials and reagents were obtained from commercial sources and were used without further purification. The FT-IR spectra were recorded on a JASCO FT-IR spectrophotometer employing a 0.1 $\mathrm{mm} \mathrm{NaCl}$ solution cell. Both ${ }^{1} \mathrm{H}$ and ${ }^{13} \mathrm{C}$ NMR spectra were recorded on a Bruker AVANCE $400 \mathrm{MHz}$ spectrometer. The chemical shifts $(\delta)$ were reported in ppm relative to TMS used as an internal standard. Mass spectra (MS) were obtained from a LC-MSD-Trap_00125 spectrometer with ESI ion source type. Reactions were monitored by thin layer chromatography (Silica gel 60 F254). Solvents were purified according to the standard. A EuroEA Elemental Analyzer performed elemental analyses.

\subsection{Chemistry}

\subsubsection{Synthesis of 2}

To a solution of $1(0.33 \mathrm{~g}, 1.0 \mathrm{mmol})$ in DCE $(10.0 \mathrm{~mL}), 2.0 \mathrm{~mL}$ of glacial AcOH was added, and the mixture was stirred under nitrogen at room temperature for $1 \mathrm{hr}$. Boc-protected spermidine $(0.35$ $\mathrm{g}, 1.0 \mathrm{mmol})$ was added and stirred under nitrogen at room temperature for $24 \mathrm{hrs}$. $\mathrm{Na}(\mathrm{OAc})_{3} \mathrm{BH}(0.28$ $\mathrm{g}, 1.3 \mathrm{mmol})$, then glacial $\mathrm{AcOH}(0.5 \mathrm{~mL})$ were added and the reaction mixture was stirred under nitrogen for $52 \mathrm{hrs}$. The reaction was neutralized with $1 \mathrm{~N} \mathrm{NaOH}$ and the product was extracted with $\mathrm{CHCl}_{3}(2 \times 20 \mathrm{~mL})$. The organic layer was washed twice with brine $(20 \mathrm{~mL})$, dried over anhydrous $\mathrm{Na}_{2} \mathrm{SO}_{4}$, and filtered. The solvent was removed under vacuum to yield a yellow oil, which was washed with ether then evaporation under vacuum, to give yellow solid. The yellow solid was dissolved in $\mathrm{CHCl}_{3}(20 \mathrm{~mL})$ and TFA $(2.2 \mathrm{~mL}, 30 \mathrm{mmol})$ was added and stirred at r.t until no starting material left. The solvent was removed under vacuum and purified by preparative TLC (5\% ammonia solution/ethanol) to furnish 2 (0.17 g, 37\%); M.p. 135-137 ${ }^{\circ} \mathrm{C}$. FTIR (KBr), $v_{\max } 3439,2947,1694,1476$ $\mathrm{cm}^{-1} .{ }^{1} \mathrm{H}-\mathrm{NMR}\left(\mathrm{CDCl}_{3}, 400 \mathrm{MHz}\right) \delta: 5.73$ (d, 1H, H-4), 3.12 (m, 4H, H-22,23), 3.0 (m, 4H, H-25,26), 2.79 (m, 2H, H-29), 1.26 (s, 3H, H-19), 0.84 (s, 3H, H-18). ${ }^{13} \mathrm{C}-\mathrm{NMR}\left(\mathrm{CDCl}_{3}, 100 \mathrm{MHz}\right) \delta: 11.2$ (C-18), 16.3 (C-19), 39.3(C-22), 54.0 (C-26), 122.8 (C-4), 173.7 (C-5), 200.9 (C-3). M.wt calcd for $\mathrm{C}_{29} \mathrm{H}_{52} \mathrm{~N}_{3} \mathrm{O}$ : $458.4110 \mathrm{~g} / \mathrm{mol}$; Found 458.4127. MS (ESI), $\mathrm{m} / \mathrm{z}$ (relative intensity): $458\left(\mathrm{M}^{+}, 100\right), 427\left(\mathrm{M}-\mathrm{CH}_{2} \mathrm{NH}_{2}\right.$, 12), $387\left(\mathrm{M}-\mathrm{C}_{4} \mathrm{H}_{8} \mathrm{NH}_{2}, 4\right)$. 


\subsubsection{Synthesis of $\mathbf{3}$}

Compound $2(0.45 \mathrm{~g}, 1.0 \mathrm{mmol})$ and cerium chloride $(0.25 \mathrm{~g}, 1.0 \mathrm{mmol})$ were dissolved in methanol $(5.0 \mathrm{~mL})$. Sodium borohydride $(38 \mathrm{mg}, 1.0 \mathrm{mmol})$ was added in one portion with stirring for $20 \mathrm{~min}$ before the $\mathrm{pH}$ was adjusted to neutral with $2 \mathrm{~N} \mathrm{HCl}$. A vigorous gas evolution occurs, together with a temperature rise $\left(\sim 35^{\circ} \mathrm{C}\right)$. The solution was extracted with chloroform $(3 \times 20 \mathrm{~mL})$, and the solvent was dried upon evaporation and purified by column chromatography (30\% EtOAc: $70 \%$ Hexane) to give the product $3(0.33 \mathrm{~g}, 75 \%)$. Mp: 310-311 (d) ${ }^{\circ} \mathrm{C}$. FTIR (KBr), $v_{\max } 3364,3223,2944,2869,1631$, $1468 \mathrm{~cm}^{-1}$. ${ }^{1} \mathrm{H}-\mathrm{NMR}\left(\mathrm{CD}_{3} \mathrm{OD}: \mathrm{CDCl}_{3}, 400 \mathrm{MHz}\right) \delta: 5.92(\mathrm{~d}, 1 \mathrm{H}, \mathrm{H}-4), 5.74(\mathrm{~s}, 1 \mathrm{H}, \mathrm{H}-3), 5.6(\mathrm{~m}, 1 \mathrm{H}$, H-6), 3.15 (m, 2H, H-22), 0.99 (s, 3H, H-19), 0.81 (s, 3H, H-18). ${ }^{13} \mathrm{C}-\mathrm{NMR}\left(\mathrm{CD}_{3} \mathrm{OD}: \mathrm{CDCl}_{3}, 100 \mathrm{MHz}\right)$

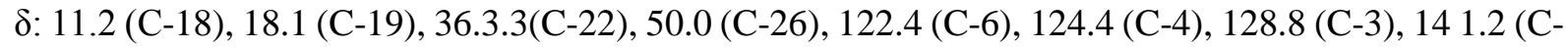
5). M.wt calcd for $\mathrm{C}_{29} \mathrm{H}_{52} \mathrm{~N}_{3}: 442.4161 \mathrm{~g} / \mathrm{mol}$; Found 442.4152. MS (ESI), $\mathrm{m} / z$ (relative intensity): 442 $\left(\mathrm{M}^{+}, 35\right), 371\left(\mathrm{M}-\mathrm{C}_{4} \mathrm{H}_{10} \mathrm{~N}, 20\right), 327\left(\mathrm{M}-\mathrm{C}_{6} \mathrm{H}_{15} \mathrm{~N}_{2}, 100\right)$.

\subsubsection{Synthesis of 4}

To a solution of $1(0.35 \mathrm{~g}, 1.0 \mathrm{mmol})$ in DCE $(10.0 \mathrm{~mL})$ was added putrescine $(0.09 \mathrm{~g}, 1.0$ $\mathrm{mmol})$, sodium triactoxyborohydride $(0.43 \mathrm{~g}, 2 \mathrm{mmol})$, and $2.0 \mathrm{~mL}$ of glacial $\mathrm{AcOH}$. The mixture was stirred under nitrogen at room temperature for $88 \mathrm{hrs}$. The reaction was neutralized with $1 \mathrm{~N} \mathrm{NaOH}$ and the product was extracted with $\mathrm{CHCl}_{3}(3 \times 20 \mathrm{~mL})$. The combined organic layer was washed twice with brine ( $20 \mathrm{~mL}$ ), dried over anhydrous $\mathrm{Na}_{2} \mathrm{SO}_{4}$, and evaporated under vacuum to yield a brown yellow oil, which was purified by column chromatography (5\% ammonia solution/ethanol) to furnish $4(0.22 \mathrm{~g}$, $62 \%$ ); M.p. $145-147^{\circ} \mathrm{C}$. FTIR (KBr), $v_{\max } 3410,2935,1675,1616 \mathrm{~cm}^{-1} .{ }^{1} \mathrm{H}-\mathrm{NMR}\left(\mathrm{CDCl}_{3}, 400 \mathrm{MHz}\right) \delta$ : 5.70 (brs, 1H, H-4), 2.60 (m, 4H, H-23, 23'), 2.34 (m, 4H, H-22, 22'), 1.51 (m, 4 H, H-24, 24'), 1.16 (s, $3 \mathrm{H}, \mathrm{H}-19), 0.70$ (s, 3H, H-18). ${ }^{13} \mathrm{C}-\mathrm{NMR}\left(\mathrm{CDCl}_{3}, 100 \mathrm{MHz}\right) \delta: 11.2$ (C-18), 16.3 (C-19), 39.3(C-22), 54.0 (C-26), 122.8 (C-4), 173.7 (C-5), 200.9 (C-3). M.wt calcd for $\mathrm{C}_{48} \mathrm{H}_{77} \mathrm{~N}_{2} \mathrm{O}_{2}: 713.5985 \mathrm{~g} / \mathrm{mol}$; Found 713.5962. MS (ESI), $m / z$ (relative intensity): $713\left(\mathrm{M}^{+}, 96\right), 413\left(\mathrm{M}-\mathrm{C}_{21} \mathrm{H}_{31} \mathrm{O}, 52\right), 384\left(\mathrm{M}^{-} \mathrm{C}_{22} \mathrm{H}_{34} \mathrm{NO}\right.$, 100).

\subsubsection{Synthesis of 5}

The dimer $4(0.37 \mathrm{~g}, 0.5 \mathrm{mmol})$ and cerium chloride $(0.125 \mathrm{~g}, 0.5 \mathrm{mmol})$ were dissolved in methanol $(5.0 \mathrm{~mL})$. Sodium borohydride $(19 \mathrm{mg}, 0.5 \mathrm{mmol})$ was added in one portion with stirring. A vigorous gas evolution occurs, together with temperature rise $\left(35^{\circ} \mathrm{C}\right)$. Stirring was continued for 20 mins befor $\mathrm{pH}$ was adjusted neutrally with $2 \mathrm{~N} \mathrm{HCl}$. The solution was extracted with chloroform $(3 \times 20$ $\mathrm{mL}$ ), and the solvent was dried to give upon evaporation the crude product, which was purified by column chromatography (70\% Hexane: $20 \%$ EtOAc: $10 \%$ EtOH) and give dimer 5 (0.34 g, 92\%). m.p. $320-323{ }^{\circ} \mathrm{C}(\mathrm{d})$. FTIR (KBr), $v_{\max } 3403,2940,2869,1671,1446 \mathrm{~cm}^{-1} .{ }^{1} \mathrm{H}-\mathrm{NMR}\left(\mathrm{CDCl}_{3}, 400 \mathrm{MHz}\right) \delta$ : 5.70 (brs, 1H, H-4), 5.23 (d, 1H, H-4), 4.05 (m, 1H, H-3'), 3.06 (m, 4H, H-22, 23), 1.51 (m, 4 H, H-24, 24), 1.23 (s, 3H, H-19), 0.77 (s, 3H, H-18), ${ }^{13} \mathrm{C}-\mathrm{NMR}\left(\mathrm{CDCl}_{3}, 100 \mathrm{MHz}\right) \delta: 10.9$ (C-18), 16.1 (C-19),

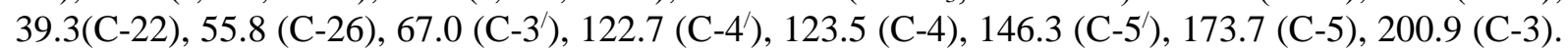
M.wt calcd for $\mathrm{C}_{48} \mathrm{H}_{79} \mathrm{~N}_{2} \mathrm{O}_{2}$ : 715.6141g/mol; Found 715.6134. MS (ESI), $m / z$ (relative intensity): 715 $\left(\mathrm{M}^{+}, 65\right), 413\left(\mathrm{M}-\mathrm{C}_{21} \mathrm{H}_{31} \mathrm{O}, 32\right), 384\left(\mathrm{M}-\mathrm{C}_{22} \mathrm{H}_{34} \mathrm{NO}, 100\right)$.

\subsubsection{Synthesis of 6}

The dimer $5(0.37 \mathrm{~g}, 0.5 \mathrm{mmol})$ and cerium chloride $(0.12 \mathrm{~g}, 0.5 \mathrm{mmol})$ were dissolved in methanol $(4.0 \mathrm{~mL})$. Sodium borohydride $(19 \mathrm{mg}, 0.5 \mathrm{mmol})$ was added in one portion with stirring. A vigorous gas evolution occur, together with a temperature raise to $\left(\sim 35^{\circ} \mathrm{C}\right)$. Stirring was continued for 20 mins before $\mathrm{pH}$ was adjusted to neutral with $2 \mathrm{~N} \mathrm{HCl}$. The product was extracted with $\mathrm{CHCl}_{3}(2 \times 20$ $\mathrm{mL})$. The organic layer was washed twice with brine $(20 \mathrm{~mL})$, dried over anhydrous $\mathrm{Na}_{2} \mathrm{SO}_{4}$, and filtered. The solvent was removed under vacuum to yield a yellow oil, which was purified by preparative TLC (5\% ammonia solution/ethanol) to furnish $6(0.26 \mathrm{~g}, 80 \%)$. M.p. $327-330{ }^{\circ} \mathrm{C}(\mathrm{d})$. FTIR $(\mathrm{KBr}), v_{\max }$ 3396, 3361, 3014, 2940, 2869, 1628, $1444 \mathrm{~cm}^{-1} .{ }^{1} \mathrm{H}-\mathrm{NMR}\left(\mathrm{CDCl}_{3}, 400 \mathrm{MHz}\right) \delta: 5.76$ (d, 2H, H-4, 4'), 5.44 (m, 2H, H-3, 3'), 5.22 (m, 2H, H-6, 6'), 2.92 (m, 4H, H-22, 22'), 2.60 (m, 4 H, H-23, 23'), 1.02 (s, 
3H, H-19), 0.67 (s, 3H, H-18), ${ }^{13} \mathrm{C}-\mathrm{NMR}\left(\mathrm{CDCl}_{3}, 100 \mathrm{MHz}\right) \delta: 11.4$ (C-18), 18.1 (C-19), 39.5(C-22), 53.5 (C-23), 122.4 (C-6), 124.5(C-4), 128.8 (C-3), 141.3 (C-5). M.wt calcd for $\mathrm{C}_{48} \mathrm{H}_{77} \mathrm{~N}_{2}$ : 681.6086g/mol; Found 681.6084. MS (ESI), $\mathrm{m} / z$ (relative intensity): $681\left(\mathrm{M}^{+}, 100\right), 397\left(\mathrm{M}_{-} \mathrm{C}_{22} \mathrm{H}_{35} \mathrm{~N}\right.$, 32), $368\left(\mathrm{M}-\mathrm{C}_{24} \mathrm{H}_{40} \mathrm{~N}, 96\right)$.

\subsubsection{Synthesis of 8}

To a solution of $7(0.14 \mathrm{~g}, 0.5 \mathrm{mmol})$ in DCE $(10.0 \mathrm{~mL})$ was added putrescine $(0.045 \mathrm{~g}, 0.5$ mmol), sodium triactoxyborohydride $(0.215 \mathrm{~g}, 1 \mathrm{mmol})$, and $2.0 \mathrm{~mL}$ of glacial $\mathrm{AcOH}$. The mixture was stirred under nitrogen at room temperature for $88 \mathrm{hrs}$. The reaction was neutralized with $1 \mathrm{~N} \mathrm{NaOH}$ and the product was extracted with $\mathrm{CHCl}_{3}(3 \times 20 \mathrm{~mL})$. The combined organic layer was washed twice with brine ( $20 \mathrm{~mL}$ ), dried over anhydrous $\mathrm{Na}_{2} \mathrm{SO}_{4}$, and evaporated under vacuum to yield a brown yellow oil, which was purified by column chromatography (5\% ammonia solution/ethanol) to furnish $\mathbf{8}(0.22 \mathrm{~g}$, $22 \%)$; M.p. $145-147^{\circ} \mathrm{C}$. FTIR (KBr), $v_{\max } 3400,2933,1685,1616 \mathrm{~cm}^{-1} .{ }^{1} \mathrm{H}-\mathrm{NMR}\left(\mathrm{CDCl}_{3}, 400 \mathrm{MHz}\right) \delta$ : 6.20 (brs, 2H, H-4, 4'), 2.80 (m, 2H, H-17, 17'), 2.52 (m, 4H, H-20, 20'), 1.54 (m, 4 H, H-21, 21'), 1.20 (s, 3H, H-19), 0.93 (s, 3H, H-18). ${ }^{13} \mathrm{C}-\mathrm{NMR}\left(\mathrm{CDCl}_{3}, 100 \mathrm{MHz}\right) \delta: 13.8$ (C-18), 17.7 (C-19), 47.7 (C21), 51.1 (C-20), 126.1 (C-4), 160.2 (C-5), 199.2 (C-3). MS (ESI), for $\mathrm{C}_{42} \mathrm{H}_{64} \mathrm{~N}_{2} \mathrm{O}_{2}, \mathrm{~m} / z$ (relative intensity): $628\left(\mathrm{M}^{+}, 96\right), 357\left(\mathrm{M}-\mathrm{C}_{19} \mathrm{H}_{27} \mathrm{O}, 35\right)$.

\section{Results and Discussion}

Reductive amination of the ketobisnoraldehyde $1(1.0 \mathrm{mmol})$ with the protected spermidine $(1.0 \mathrm{mmol})$ in DCE using $\mathrm{NaBH}_{3} \mathrm{CN}$ as the reducing agent followed by reaction with TFA in $\mathrm{CHCl}_{3}$ to remove the protecting group on the polyamine gave the polyaminosteroid $\mathbf{2}$ in $37 \%$ yield. The structure of compound 2 was characterized by ${ }^{1} \mathrm{H}-\mathrm{NMR}$ that showed the peak at $5.73 \mathrm{ppm}$ characteristic of the hydrogen on C-4, while the aldehyde peak was replaced by a peak at $3.12 \mathrm{ppm}$ characteristic of the methylene units at C-22 and C-23(as shown in Scheme 1). The ${ }^{13} \mathrm{C}-\mathrm{NMR}$ showed the peak at $200 \mathrm{ppm}$ characteristic of the 3-keto group and the two olefinic peaks at 173, and 122 ppm characteristic of C-5 and C-4, respectively.

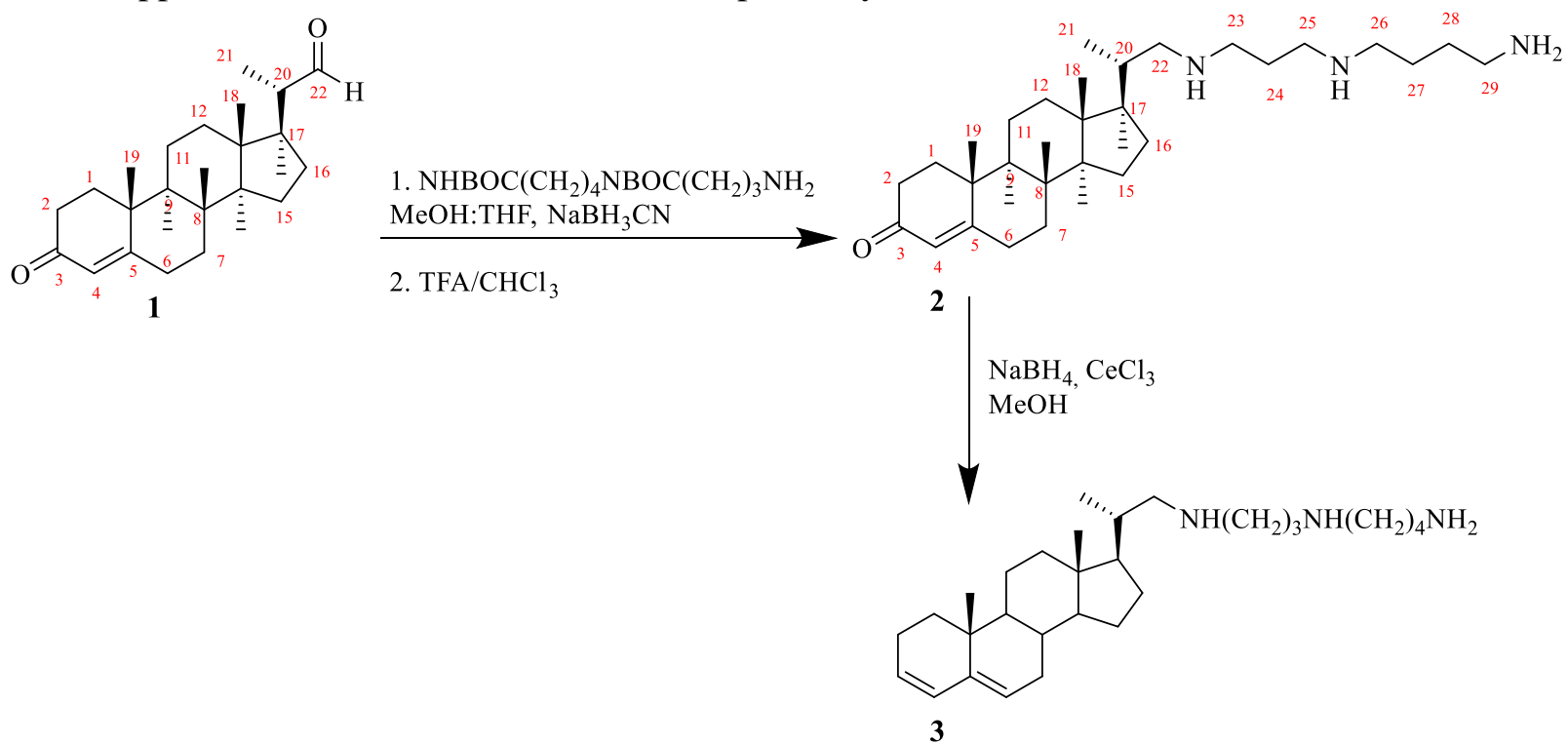

Scheme 1. Synthesis of spermidine steroidal diene 3

The next target structure was to prepare squalamine analog that has a hydroxyl group on the other end of the steroid (i.e, on the A ring together with the polyamine on the D ring). A Luche reduction applied to effect the 1,2 reduction of steroidal $\alpha$-enones. Surprisingly, reduction of the 
enone system in compound $2(1.0 \mathrm{mmol})$ with $\mathrm{NaBH}_{4}(1.0 \mathrm{mmol})$ and cerium chloride $(1.0 \mathrm{mmol})$ in $\mathrm{MeOH}$ (Scheme 1) gave compound 3, in which the enone system was reduced and the allylic alcohol dehydrated producing the diene system. It is believed that the polyamine side chain plays a role in this transformation, because there is no example in literature that reports the formation of a 1,3-diene from a regular enone system using these (Luche) reagents. ${ }^{1} \mathrm{H}$ NMR of compound 3 showed a singlet at $5.7 \mathrm{ppm}$ for the hydrogen at C-3, a doublet at $5.9 \mathrm{ppm}$ for hydrogen on C-4 and a multiplet at $5.6 \mathrm{ppm}$ for the hydrogen at C- $6 .{ }^{15}$

A possible mechanism for the transformation of compound $\mathbf{2}$ to $\mathbf{3}$ is shown in Scheme 2.

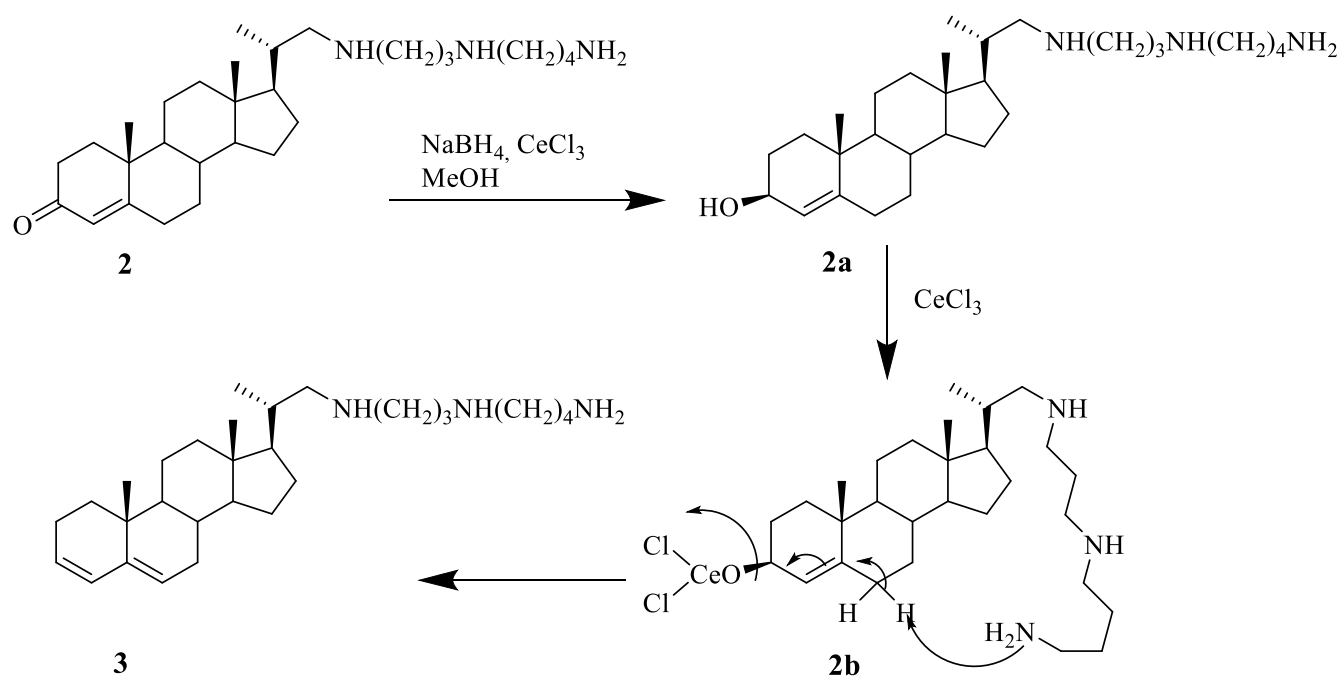

Scheme 2. Possible mechanism for the reduction step

By using the same reductive amination method, the dimer 4 was synthesized in $62 \%$ yield. Reductive amination of ketobisnoraldehyde $1(1.0 \mathrm{mmol})$ and putrescine $(1.0 \mathrm{mmol})$ in DCE using $\mathrm{NaBH}(\mathrm{OAc})_{3}$ as a reducing agent (Scheme 3) proved successful. The ${ }^{1} \mathrm{H}-\mathrm{NMR}$ for the dimer 4 showed a doublet at $5.7 \mathrm{ppm}$ characteristic of hydrogen on $\mathrm{C}-4$, and multiplet centered at 2.34 and $2.60 \mathrm{ppm}$, characteristic of the steroidal methylene unit at $\mathrm{C}-22$, and putrescine methylene unit $\mathrm{C}$ 23 respectively. The ${ }^{13} \mathrm{C}-\mathrm{NMR}$ for the same compound proved that the structure of $\mathbf{4}$ is symmetrical; showing only 22 peaks, which corresponds to half the compound. Our initial goal was to reduce the carbonyl group at C-3 in order to increase the solubility of the compound in aqueous media, as well as to build a molecule that mimics the structure of squalamine (polyamine and hydroxyl functionality). The reducing agent that was used before $\left(\mathrm{NaBH}_{4} / \mathrm{CeCl}_{3}\right)$ gave the diene system. We were interested to learn if the dimer would do the same in the reduction process.

Treatment of the dimer $4(1.0 \mathrm{mmol})$ with $\mathrm{NaBH}_{4}(1.0 \mathrm{mmol})$ and $\mathrm{CeCl}_{3}(1.0 \mathrm{mmol})$ in $\mathrm{MeOH}$ gave compound $\mathbf{5}$ in $92 \%$ yield. Interestingly, only one carbonyl group was reduced and the 3 hydroxyl compound 4 was produced, and not the diene. (Scheme 3). The ${ }^{\mathrm{I}} \mathrm{H}-\mathrm{NMR}$ showed the peak at $5.70 \mathrm{ppm}$ characteristic of the hydrogen on C-3 and the peak at $4.0 \mathrm{ppm}$ characteristic of the axial hydrogen on C-3. The ${ }^{13} \mathrm{C}-\mathrm{NMR}$ gave more information and showed the peaks at 200, 173, $123 \mathrm{ppm}$, are characteristic for C-3, C-5 and C-4, respectively. The other peaks at 67, 146 and 123 $\mathrm{ppm}$, are characteristic for $\mathrm{C}-3^{\prime}, \mathrm{C}-5^{\prime}$ and $\mathrm{C}-4^{\prime}$ respectively. It was suggested that one equivalent of $\mathrm{NaBH}_{4} / \mathrm{CeCl}_{3}$ reduce only one side of the enone system because the steroids might stack on top of each other.

In order to make the explanation more clear, the second equivalent of $\mathrm{NaBH}_{4} / \mathrm{CeCl}_{3}$ was used to reduce compound 5 and the result was the formation of the diene $\mathbf{6}$ in $80 \%$ yield. One possible explanation is that the $\mathrm{CeCl}_{3}$ complexes to the hydroxyl group at $\mathrm{C}-3$ and dehydration occurs in the same way that was explained as on Scheme 2 that give the diene on one side. The molecule subsequently changed its geometry and the other carbonyl group was now accessible to the reducing agent, thus the same thing that occurred on the first side could happen on the opposite side (i.e. reduction of the enone to allylic alcohol then dehydration to give the diene). 
The ${ }^{1} \mathrm{H}-\mathrm{NMR}$ for the diene $\mathbf{6}$ showed peaks at 5.76, 5.44, and $5.22 \mathrm{ppm}$ characteristic of the hydrogen on C-4, C-3 and C-6, respectively. The ${ }^{13} \mathrm{C}-\mathrm{NMR}$ showed the peaks at 141,128 , 124, and $122 \mathrm{ppm}$ characteristic of C-5, C-3, C-4, and C-6, respectively, in addition to the peaks at 56 , and $53 \mathrm{ppm}$ of the $\mathrm{C}-22$, and $\mathrm{C}-23$ that are next to the nitrogen.

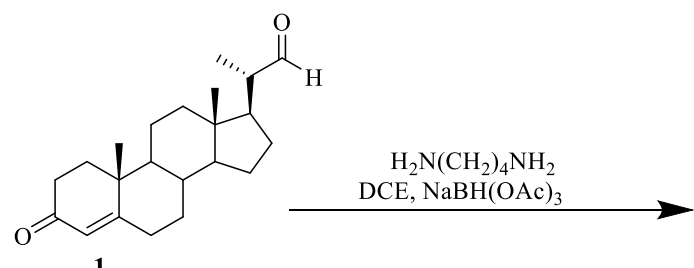

1
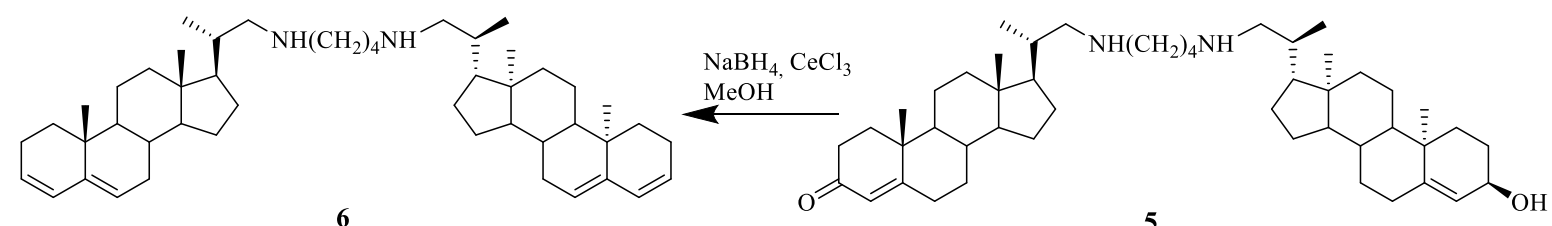

Scheme 3. Synthesis of putrescine steroidal diene dimer

In our attempts to prove the importance of the amine functionality role in the dehydration step, we tried the same reduction conditions on different $\alpha, \beta$-unsaturated ketones, but all what we got was the allyl alcohol products. One of the readily available diketone we used was 4Androsten-3,17-dione 7. Therefore, we decided to synthesize the diamine dimer $\mathbf{8}$ then reduced it to the diene as in Scheme 4. Attempts to reduce the dimer $\mathbf{8}$ directly with $\mathbf{2}$ equiv of $\mathrm{NaBH}_{4} / \mathrm{CeCl}_{3}$ but unfortunately, no reduction observed by TLC and NMR. We believe that the reason is the rigidity of the dimer $\mathbf{8}$, where the amine is not accessible to act as a base and do the dehydration step. The reduction of these types of dimers are currently undergoing further investigations.<smiles>CC1(C)C2CCC3CCC(=O)C=C3CC3C2CCC31C</smiles>

7

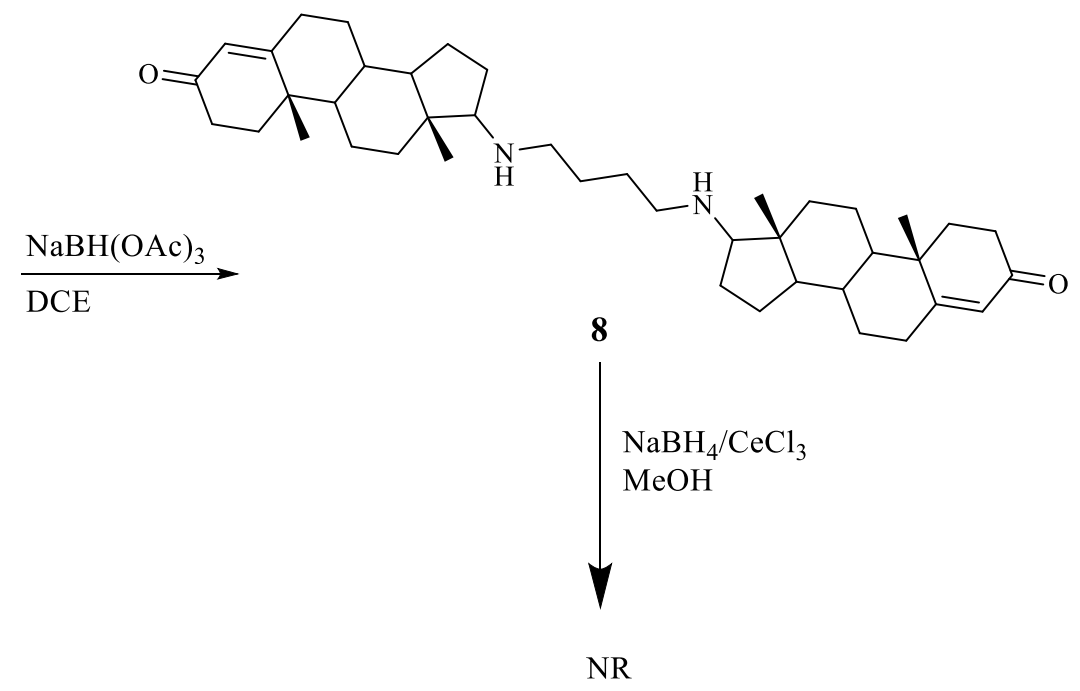

Scheme 4. Attempts for the synthesis of putrescine steroidal dimer $\mathbf{8}$ 


\section{Acknowledgements}

The authors would like to express their gratitude for the financial support that was provided by Jordan University of Science \& Technology.

\section{ORCID}

Khaled Q. Shawakfeh: 0000-0001-5308-5712

Raed Al-Zoubi: 0000-0002-0548-429X

Walid Al-Jammal: 0000-0003-4355-6431

Rasha Nusier: 0000-0001-7302-6023

\section{References}

[1] Varma, R. S.; Kabalka, G. W. Synthesis of Alkylamines via Reduction of Nitroalkenes using in situ Prepared BH3·THF. Synth. Commun. 1985, 15, 985- 990.

[2] Nutaitis, C. F.; Bernardo, J. E. Regioselective 1,2-reduction of conjugated enones and enals with sodium monoacetoxyborohydride: preparation of allylic alcohols. J. Org. Chem. 1989, 54, 5629-5630.

[3] Muller, J. C.; Stangeland, E. L.; Goralski, C. T.; Singaram, B. Aminoborohydrides. 2. Regiospecific reductions of $\alpha, \beta$-unsaturated carbonyl compounds with lithium pyrrolidinoborohydride. A facile conversion of $\alpha, \beta$-unsaturated aldehydes and ketones to the corresponding allylic alcohols in high purity. Tetrahedron Lett. 1993, 34, 257-260.

[4] Fortunato, J. M.; Ganem, B. Lithium and potassium trialkylborohydrides. Reagents for direct reduction of .alpha.,.beta.-unsaturated carbonyl compounds to synthetically versatile enolate anions. J. Org. Chem. 1976, 41, 2194-2200.

[5] Luche, J. L. Lanthanides in organic chemistry. 1. Selective 1,2 reductions of conjugated ketones. J. Am. Chem. Soc. 1978, 100, 2226- 2227.

[6] Gemal, A. L.; Luche, J. L. Lanthanoids in organic synthesis. 6. Reduction of .alpha.-enones by sodium borohydride in the presence of lanthanoid chlorides: synthetic and mechanistic aspects. J. Am. Chem. Soc. 1981, 103, 5454-5459.

[7] a)Davood, S.; Mehdi, R. Efficient and convenient reduction of organic carbonyl compounds to their corresponding alcohols by $\mathrm{Zn}\left(\mathrm{BH}_{4}\right)_{2} /$ charcoal in THF. J. Mex. Chem. Soc. 2012, 56(2), 169-175.

b) Forkel, N. V. Lanthanide replacement in organic synthesis: Calcium-mediated Luche-type reduction of $\alpha, \beta$-functionalised ketones, Ph.D thesis, Imperial College London, UK, 2013.

[8] Fleming, I. Forontier Orbitals and Organic Chemical Reactions, Wiley Ed.:London, England, 1976.

[9] Yuan, H.; Chen, H.; Jin, H.; Li, B.; Shen, Y.; Shan, L.; Sun, Q.; Zhang, W. Deoxygenation of $\alpha, \beta-$ unsaturated acylphenols through ethyl o-acylphenylcarbonates with Luche reduction. Tetrahedron Lett. 2013, 54, 2776-2780.

[10] Herbst, RS; Hammond, LA; Carbone, DP. A phase I/IIA trial of continuous five-day infusion of squalamine lactate (MSI-1256F) plus carboplatin and paclitaxel in patients with advanced non-small cell lung cancer. Clin Cancer Res. 2003, 9, 4108-15.

[11] Shawakfeh, K. Q.; Al-Said, N. H.; Shawish, I. Synthesis and Characterization of New Polyamino Cholic Acid Dimmers. Asian J. Chem. 2005, 17, 91-97.

[12] Shawakfeh, K. Q.; Al-Ajlouni, A.; Ibdah, A. Synthesis and Selective Catalytic Oxidation of New Dimeric Steroids. Acta Chim. Slov. 2002, 49, 805-813.

[13] Shawakfeh KQ, Al-Said NH, Al- Zoubi RM. Synthesis of bis-diosgenin pyrazine dimers: new cephalostatin analogs. Steroids 2008;73/6:579-84.

[14] Shawakfeh KQ, Al-Said NH. Synthesis of new symmetrical bis-steroidal pyrazine analogues from diosgenin. Steroids, 2011,76, 232-237.

[15] Shawakfeh, K. The Synthesis, Characterization, and Biological Testing of New Squalamine Analogs, Ph.D thesis, Temple University, 1998.

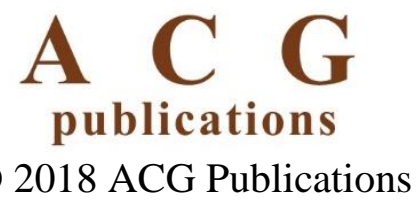

